\title{
Timothy Syndrome 1.1: A Timothy Syndrome 1 Genotype without Syndactyly and Major Extracardiac Manifestations
}

Róbert Sepp, ${ }^{1}$ Lidia Hategan, ${ }^{1}$ Attila Bácsi, ${ }^{2}$ Judit Cseklye,${ }^{3}$ László Környei, ${ }^{4}$ János Borbás, ${ }^{1}$ Márta Széll, ${ }^{5}$ Tamás Forster, ${ }^{1}$ István Nagy, ${ }^{3,6}$ Zoltán Hegedüs ${ }^{7}$

\section{Affiliations:}

${ }^{1}$ 2nd Department of Internal Medicine and Cardiology Center, University of Szeged, Hungary ${ }^{2}$ Fejér County “Szent György” University Teaching Hospital, Székesfehérvár, Hungary ${ }^{3}$ Seqomics Biotechnology Ltd., Mórahalom, Hungary

4"Gottsegen György" National Institute of Cardiology, Budapest, Hungary

${ }^{5}$ Department of Medical Genetics, University of Szeged, Hungary

Institutes of Biochemistry ${ }^{6}$ and Biophysics ${ }^{7}$, Biological Research Centre, Szeged, Hungary

\section{Corresponding author:}

Name: Dr. Róbert Sepp, MD, PhD

Address: 2nd Department of Internal Medicine and Cardiology Centre, Faculty of Medicine, University of Szeged, Semmelweis str. 8, 6725 Szeged, Hungary

Phone: +36-62-545-220

Fax: +36-62-544-568

Email: sepp.robert@med.u-szeged.hu; sepprobert@gmail.com

Running Title: Sepp et al. Timothy syndrome 1 genotype without syndactyly

Conflict of interest: The authors have no conflict of interests to declare. 


\section{ABSTRACT}

Timothy syndrome 1 (TS1) is a rare genetic disorder characterized by multisystem abnormalities including QT prolongation, congenital heart defects, facial dysmorphism, episodic hypoglycemia and neurological symptoms. A morphological hallmark of TS1 is syndactyly, present in all cases. TS1 is caused by the canonical p.Gly406Arg mutation in the alternatively spliced exon $8 \mathrm{~A}$ in the $C A C N A 1 C$ gene, encoding for the main cardiac L-type calcium channel. A variant case of TS1 is reported. The proband had intermittent fetal bradycardia with heart rate of $72 \mathrm{bpm}$. On the first day of life bradycardia due to 2:1 atrioventricular (AV) block and marked QTc prolongation of $600 \mathrm{~ms}$ was noted. On medical therapy with propranolol and mexiletine 1:1 AV conduction returned with QTc prolongation of 470-580 ms. The patient lacked other extracardiac manifestations, most importantly syndactyly, neurological complications or autism. On genetic analysis, the canonical TS1 causing mutation, p.Gly406Arg in exon $8 \mathrm{~A}$ of the CACNAIC gene was detected. The CACNA1C p.Gly406Arg variant was not present in the parents, but was detected in the buccal DNA sample of the index patient. Our case highlight further phenotypic variability in TS. Most importantly, it underlines that the lack of syndactyly does not exclude the presence of a TS1 genotype. 
Sepp et al.

\section{KEY WORDS}

Timothy syndrome

CACNAIC gene

AV block

QTc prolongation

syndactyly 


\section{INTRODUCTION}

Timothy syndrome (TS) is a very rare genetic disorder which is characterized by numerous multisystem abnormalities leading to clinically two distinct forms of the syndrome (reviewed in [Liao and Soong 2010]). Timothy syndrome 1 (TS1) is characterized by QT prolongation, congenital heart defects (including patent ductus arteriosus, patent foramen ovale, and ventricular septal defect), facial dysmorphisms (including a flat nasal bridge, small upper jaw, low-set ears, or small and misplaced teeth), episodic hypoglycemia and neurologic symptoms including developmental delays, autism, seizures, and intellectual disability [Splawski et al. 2004]. A morphological hallmark of TS1 is syndactyly, which is reported to be present in 100\% of the cases (Table 1) [An et al. 2013; Corona-Rivera et al. 2015; Dufendach et al. 2013; Ergul et al. 2015; Etheridge et al. 2011; Krause et al. 2011; Lo et al. 2005; Splawski et al. 2004]. Timothy syndrome 2 (TS2) patients have no syndactyly but carry the other multisystem manifestations of the disease [Diep and Seaver 2015; Frohler et al. 2014; Hiippala et al. 2015; Philipp and Rodriguez 2016; Splawski et al. 2005]. Because of extreme QT prolongation, individuals with TS can experience ventricular tachycardia/fibrillation (VT/VF) and cardiac arrest, and the overall complications of multisystem abnormalities often lead to early death.

The predominant genetic cause of TS1, identified in 2004 [Splawski et al. 2004], was a recurrent, canonical 'de novo' heterozygous missense mutation, p.Gly406Arg, in the alternatively spliced exon $8 \mathrm{~A}$ in the $C A C N A 1 C$ gene, encoding for the main cardiac L-type calcium channel, $\mathrm{Ca}_{\mathrm{v}} 1.2$. In cases with TS2, 2 additional mutations, p.Gly406Arg and p.Gly402Ser, were identified in exon 8 of the $C A C N A 1 C$ gene [Splawski et al. 2005]. Exons 8 and $8 \mathrm{~A}$ of the $C A C N A 1 C$ gene undergo alternative splicing in a mutually exclusive manner, with exon 8 being the predominantly expressed isoform. Recently some other mutations, all 
affecting the CACNAIC gene, were reported in TS patients [Boczek et al. 2015; Gillis et al. 2012; Wemhoner et al. 2015].

Here we report a variant case of Timothy syndrome, named Timothy syndrome 1.1, manifested as neonatal 2:1 AV block and marked QT prolongation. Genetic analysis revealed a $C A C N A 1 C$ gene exon $8 \mathrm{~A}$ p.Gly406Arg mutation, thereby defining the case as Timothy syndrome 1 on genetic grounds. However, the patient lacks many of the other hallmarks of TS1, most notably syndactyly, and also other major extracardiac manifestations.

\section{PATIENT AND METHODS}

\section{Clinical report}

The proband was born as a second child to a healthy 31-year-old woman and 31-year-old man, both of Caucasian descent. There was no report of consanguinity, and the family histories were non-contributory. Especially, family history was negative for premature sudden cardiac death, arrhythmic disorders, syndactyly, facial dysmorphism or autism. The pregnancy was uncomplicated. Intermittent fetal bradycardia (heart rate of $72 \mathrm{bpm}$ ) was noted at 37 weeks gestation. The baby was born via normal uncomplicated vaginal delivery at 38 weeks gestation. Apgar scores were 9 and 10 at one and 5 minutes, respectively. The baby's birth weight was $2950 \mathrm{~g}$ (18th centile), length was $54 \mathrm{~cm}$ (98th centile), and head circumference measured $34 \mathrm{~cm}$ ( 35 th centile). On the second day of life cardiac evaluation revealed bradycardia due to 2:1 atrioventricular (AV) conduction and marked QTc-interval prolongation of $600 \mathrm{~ms}$ (Figure 1, Panel A). On medical therapy (propranolol and mexiletine) QTc duration stabilized in the range of 470-580 ms; 2:1 AV conduction resolved, and there was consistent 1:1 AV conduction with T-wave alternans (Figure 1, Panel B). Initial imaging with echocardiography demonstrated a patent foramen ovale, with a diameter of $2.5 \mathrm{~mm}$ with left-to-right shunt, and a mildly dilated right ventricle. The Botall duct was closed and there were no signs of ventricular septal defect, cardiomyopathy or ventricular dysfunction. 
Laboratory findings did not reveal hypoglycemia or hypocalcaemia. The patient did not have facial dysmorphisms (hypertelorism, flattened nasal bridge, prominent forehead, etc.) and was not bald. He did not have joint hypermobility. Most importantly no syndactyly, either on the hands or on the feet, were present (Figure 1, Panel C and D). No hypoplastic teeth and decay was noted. During his first three years of life he has made steady developmental progress. He sat unassisted at age 7.5 months, crawled at age 8 months, walked with support at age 8.5 months and walked independently at age 12 months. First words were at age 14 months. At age 2 years an M-CHAT (Modified Checklist for Autism in Toddlers) test was done which did not indicate autism or autism spectrum disorder. He does not have frequent or serious infections. As the patient's father is a board certified cardiologist, he is under continuous bedside ECG monitoring during nights with frequent traditional Holter monitoring performed in every 3-6 month. Only at one occasion a 2:1 AV conduction was detected for 12 hours, without symptoms, but no sustained or non-sustained ventricular tachyarrhythmias were ever encountered.

At age 2 years he was hospitalized because of an episode of severe hypoglycemia (blood glucose level $1.4 \mathrm{mmol} / \mathrm{l}$ ) associated with convulsions. As head trauma could not be excluded, a cranial CT was performed under general anesthesia. No VT or VF was observed under medication with propofol, midazolam, fentanyl and muscle relaxants. The only observed rhythm disturbance was an intermittent 2:1 AV block which returned to normal conduction after the correction of serum glucose levels. The episode resolved without any further consequence. Glucose monitoring with tissue glucose sensor did not reveal any further episode of hypoglycemia in the subsequent days. At present, at age 3 years, his mental and physical development seems to be undisturbed. He is in a good general health and attends kindergarten without assistance. He is able to express feelings, understands jokes and sadness. Molecular genetic analysis 
The investigations were approved by the Institutional Ethics Committee of the University of Szeged, and conducted according to the Helsinki declaration. Family members and the patient's care-givers gave prior written informed consent to the molecular genetic analysis. Coding sequences and exon-intron boundaries of all 13 causative long QT genes were analyzed by next-generation sequencing using Agilent's SureSelect technology with customdesigned 120-mer RNA baits specific to target region (Agilent Technologies, Santa Clara, CA, United States). Targeted resequencing was carried out on a SOLiD 5500xl System (Life Technologies, Grand Island, NY, United States). Variants, identified by targeted resequencing, were validated by standard capillary sequencing using custom-designed primers. Exon 37 of $A N K 2$ gene, exon $8 \mathrm{~A}$ of $C A C N A 1 C$ gene, and exon 1 of $K C N Q 1$ gene were direct-sequenced on a ABI Prism 310 Genetic Analyzer (Applied Biosystems by Life Technologies, Grand Island, NY, United States). Genetic mosaicism was assessed in the index patient and both parents using DNA extracted from buccal cells and from sperm, in case of father.

Mapping of the SOLiD reads were accomplished by Genomic Workbench ver 7.0.3 (CLC Bio, now part of Qiagen) using the human genome assembly hg19 as reference sequence. Variant calling and variant annotation were performed by the same software. The functional impact of amino acid changes caused by missense mutations was predicted by SIFT and PROVEAN programs. Nucleotide and amino acid changes are reported according to the Ensembl database (release: 85), based on reference sequences ENST00000155840.9 for KCNQ1, ENST00000399591.5 for CACNAIC and ENST00000264366.10 for ANK2.

\section{RESULTS}

\section{Mutation data}

Three different heterozygous genetic variants in three genes have been detected using targeted resequencing by next-generation sequencing: p.Gly406Arg (c.1216G>A, rs79891110) in exon 
8A of the CACNA1C gene (Figure 2); p.Tyr94Cys (c.281A>G, rs781717051) in exon 1 of the KCNQ1 gene; and p.Ile3252Thr (c.9755T>C, rs36210417) in exon 37 of the ANK2 gene. All three variants were previously reported. The $K C N Q 1$ p.Tyr94Cys variant was predicted to be deleterious by PROVEAN and to be tolerant by SIFT. The ANK2 p.Ile3252Thr variant was predicted to be neutral/tolerant by both prediction methods. The identified CACNAIC gene exon 8A p.Gly406Arg variant is the canonical Timothy syndrome 1 causing mutation. Although sequence homology is high between exons 8 and $8 \mathrm{~A}$ of the CACNAIC gene, the presence of several "exon specific" nucleotides made possible to distinguish between the two

(Figure 2). Sequence comparison with all available published sequences of CACNAIC exon 8 and $8 \mathrm{~A}$ in previous reports proved that our patient indeed carried the p.Gly406Arg variant affecting exon $8 \mathrm{~A}$ of the CACNAIC gene. The CACNA1C p.Gly406Arg variant was also present in the DNA sample of the index patient extracted from buccal cells. The height of the mutant nucleotide peak was similar in both samples and were equal to the normal nucleotide peak (Figure 2).

\section{Family screening}

First degree family members of the index patient (mother, father and sister) underwent genetic screening for all three variants. The proband's father was proved to be carrier of the $K C N Q 1$ p.Tyr94Cys variant, while mother and sister were non-carriers for both the $K C N Q 1$ and $A N K 2$ variants. Neither the parents nor the sister of the index patient carried the CACNAIC p.Gly406Arg variant (Figure 2), therefore this variant must have arisen 'de novo' (paternity was proven). The $K C N Q 1$ p.Tyr94Cys variant-carrying father has no signs or symptoms of long QT syndrome and has a completely normal ECG and echocardiogram (data not shown), suggesting that the KCNQ1 p.Tyr94Cys variant has no major influence on the disease phenotype. 
In order to assess whether the CACNA1C Gly406Arg mutation is indeed arisen ' $d e$ novo' in the family, or one of the parents has mosaicism for the mutation, we performed genetic analysis of the DNA extracted from buccal cells (in case of both parents) and sperm (in case of father). The CACNA1C Gly406Arg variant was not present in any sample extracted from different tissues, therefore no proof for genetic mosaicism was found (data not shown).

\section{DISCUSSION}

Here we report a variant case of Timothy syndrome, referred to as Timothy syndrome 1.1, caused by a TS1-specific CACNAIC exon 8A p.Gly406Arg mutation. The clinical phenotype was characterized by neonatal 2:1 AV block and marked QT prolongation. However, the patient lacked many of the other hallmarks of TS1, most notably syndactyly, and no other major extracardiac manifestations were present.

Syndactyly is reported in $100 \%$ of patients with CACNAIC exon 8A p.Gly406Arg mutation (Table 1). Moreover, syndactyly was also present in patients proved to be somatic or germline mosaic carriers of the mutation [Dufendach et al. 2013; Etheridge et al. 2011]. In one of these cases the direct presence of the CACNA1C exon 8A p.Gly406Arg mutation was demonstrated in left/right arm skin biopsy samples with an estimated percent mosaicism of $\sim 6.5 \%$ [Dufendach et al. 2013]. As $\mathrm{Ca}_{\mathrm{v}} 1.2$ was highly expressed in apical ectodermal ridge cells of developing digits, syndactyly is thought to be caused in TS by $\mathrm{Ca}^{2+}$-induced cell death in the apical ectodermal ridge [Splawski et al. 2004].

The most probable explanation for the lack of syndactyly and major extracardiac manifestations in our case is the presence of somatic mosaicism in our patient. The mutant $\mathrm{Ca}_{\mathrm{v}} 1.2$ channel must be absent from unaffected organs (limbs, brain) and might be present in low levels in probably affected organs (heart, pancreas) in our patient. However, as we had only two sources of tissue (lymphocytes, buccal cells), and both were shown to harbor the mutation, direct evidence for the above explanation is lacking. 
Reports on mosaic patients with TS1 describe a partial phenotype of the disease, similar to ours. These patients are usually parents of a more severely affected proband with genetically confirmed mosaicism with the potential to transmit the TS1-causative mutation to their offspring, resulting in fully expressive TS1. Dufendach et al reported a mosaic female patient who had right-sided syndactyly and was the mother of a newborn boy who presented with syndactyly, extreme QT prolongation and 2:1 atrioventricular block during syndactylycorrective surgery [Dufendach et al. 2013]. The mother didn't have evidence of QT prolongation or other TS1 manifestation. In a report by Etheridge et al. two TS1 mosaic patients were described [Etheridge et al. 2011]. One was the father of a patient with TS1 in whom mosaicism was detected. The father had complete cutaneous syndactyly of the right and left feet, but had no other dysmorphic features. He was cognitively normal and never had syncope or seizure. ECG demonstrated a prolonged QTc of $480 \mathrm{~ms}$. The other patient was a 14-year-old girl who had a cardiac arrest with documented ventricular fibrillation that occurred while making a phone call. She had a prolonged QTc interval of $560 \mathrm{~ms}$ and bilateral syndactyly involving the hands and the feet, but no other manifestation of TS1. The possible presence of somatic mosaicism was also reported with regard to TS2 [Hiippala et al. 2015; Splawski et al. 2005].

In conclusion, we described a Timothy syndrome 1 genotype without syndactyly and major extracardiac manifestations. The case highlight further phenotypic variability in Timothy syndrome. Most importantly, it underlines that the lack of syndactyly doesn't exclude the presence of Timothy syndrome 1 genotype.

\section{ACKNOWLEDGEMENTS}

The work was funded by the University of Szeged. The skillful assistance of Ms. Molnár Jánosné Klári is gratefully acknowledged. IN was supported by the János Bolyai Research Scholarship of the Hungarian Academy of Sciences. 


\section{REFERENCES}

An HS, Choi EY, Kwon BS, Kim GB, Bae EJ, Noh CI, Choi JY, Park SS. 2013. Sudden cardiac arrest during anesthesia in a 30-month-old boy with syndactyly: a case of genetically proven Timothy syndrome. J Korean Med Sci 28(5):788-791.

Boczek NJ, Miller EM, Ye D, Nesterenko VV, Tester DJ, Antzelevitch C, Czosek RJ, Ackerman MJ, Ware SM. 2015. Novel Timothy syndrome mutation leading to increase in CACNA1C window current. Heart Rhythm 12(1):211-219.

Corona-Rivera JR, Barrios-Prieto E, Nieto-Garcia R, Bloise R, Priori S, Napolitano C, Bobadilla-Morales L, Corona-Rivera A, Zapata-Aldana E, Pena-Padilla C, RiveraVargas J, Chavana-Naranjo E. 2015. Unusual retrospective prenatal findings in a male newborn with Timothy syndrome type 1. Eur J Med Genet 58(6-7):332-335.

Diep V, Seaver LH. 2015. Long QT syndrome with craniofacial, digital, and neurologic features: Is it useful to distinguish between timothy syndrome types 1 and 2? Am J Med Genet A 167A(11):2780-2785.

Dufendach KA, Giudicessi JR, Boczek NJ, Ackerman MJ. 2013. Maternal mosaicism confounds the neonatal diagnosis of type 1 Timothy syndrome. Pediatrics 131(6):e1991-1995.

Ergul Y, Ozyilmaz I, Haydin S, Guzeltas A, Tuzcu V. 2015. A rare association with suffered cardiac arrest, long QT interval, and syndactyly: Timothy syndrome (LQT-8). Anatol J Cardiol 15(8):672-674.

Etheridge SP, Bowles NE, Arrington CB, Pilcher T, Rope A, Wilde AA, Alders M, Saarel EV, Tavernier R, Timothy KW, Tristani-Firouzi M. 2011. Somatic mosaicism contributes to phenotypic variation in Timothy syndrome. Am J Med Genet A $155 \mathrm{~A}(10): 2578-2583$. 
Frohler S, Kieslich M, Langnick C, Feldkamp M, Opgen-Rhein B, Berger F, Will JC, Chen W. 2014. Exome sequencing helped the fine diagnosis of two siblings afflicted with atypical Timothy syndrome (TS2). BMC Med Genet 15:48.

Gillis J, Burashnikov E, Antzelevitch C, Blaser S, Gross G, Turner L, Babul-Hirji R, Chitayat D. 2012. Long QT, syndactyly, joint contractures, stroke and novel CACNA1C mutation: expanding the spectrum of Timothy syndrome. Am J Med Genet A 158A(1):182-187.

Hiippala A, Tallila J, Myllykangas S, Koskenvuo JW, Alastalo TP. 2015. Expanding the phenotype of Timothy syndrome type 2: an adolescent with ventricular fibrillation but normal development. Am J Med Genet A 167A(3):629-634.

Krause U, Gravenhorst V, Kriebel T, Ruschewski W, Paul T. 2011. A rare association of long QT syndrome and syndactyly: Timothy syndrome (LQT 8). Clin Res Cardiol 100(12):1123-1127.

Liao P, Soong TW. 2010. CaV1.2 channelopathies: from arrhythmias to autism, bipolar disorder, and immunodeficiency. Pflugers Arch 460(2):353-359.

Lo ANSM, Wilde AA, van Erven L, Blom NA. 2005. Syndactyly and long QT syndrome (CaV1.2 missense mutation G406R) is associated with hypertrophic cardiomyopathy. Heart Rhythm 2(12):1365-1368.

Philipp LR, Rodriguez FH, 3rd. 2016. Cardiac arrest refractory to standard intervention in atypical Timothy syndrome (LQT8 type 2). Proc (Bayl Univ Med Cent) 29(2):160162.

Splawski I, Timothy KW, Decher N, Kumar P, Sachse FB, Beggs AH, Sanguinetti MC, Keating MT. 2005. Severe arrhythmia disorder caused by cardiac L-type calcium channel mutations. Proc Natl Acad Sci U S A 102(23):8089-8096; discussion 80868088 . 
Splawski I, Timothy KW, Sharpe LM, Decher N, Kumar P, Bloise R, Napolitano C, Schwartz PJ, Joseph RM, Condouris K, Tager-Flusberg H, Priori SG, Sanguinetti MC, Keating MT. 2004. Ca(V)1.2 calcium channel dysfunction causes a multisystem disorder including arrhythmia and autism. Cell 119(1):19-31.

Wemhoner K, Friedrich C, Stallmeyer B, Coffey AJ, Grace A, Zumhagen S, Seebohm G, Ortiz-Bonnin B, Rinne S, Sachse FB, Schulze-Bahr E, Decher N. 2015. Gain-offunction mutations in the calcium channel CACNA1C (Cav1.2) cause non-syndromic long-QT but not Timothy syndrome. J Mol Cell Cardiol 80:186-195. 

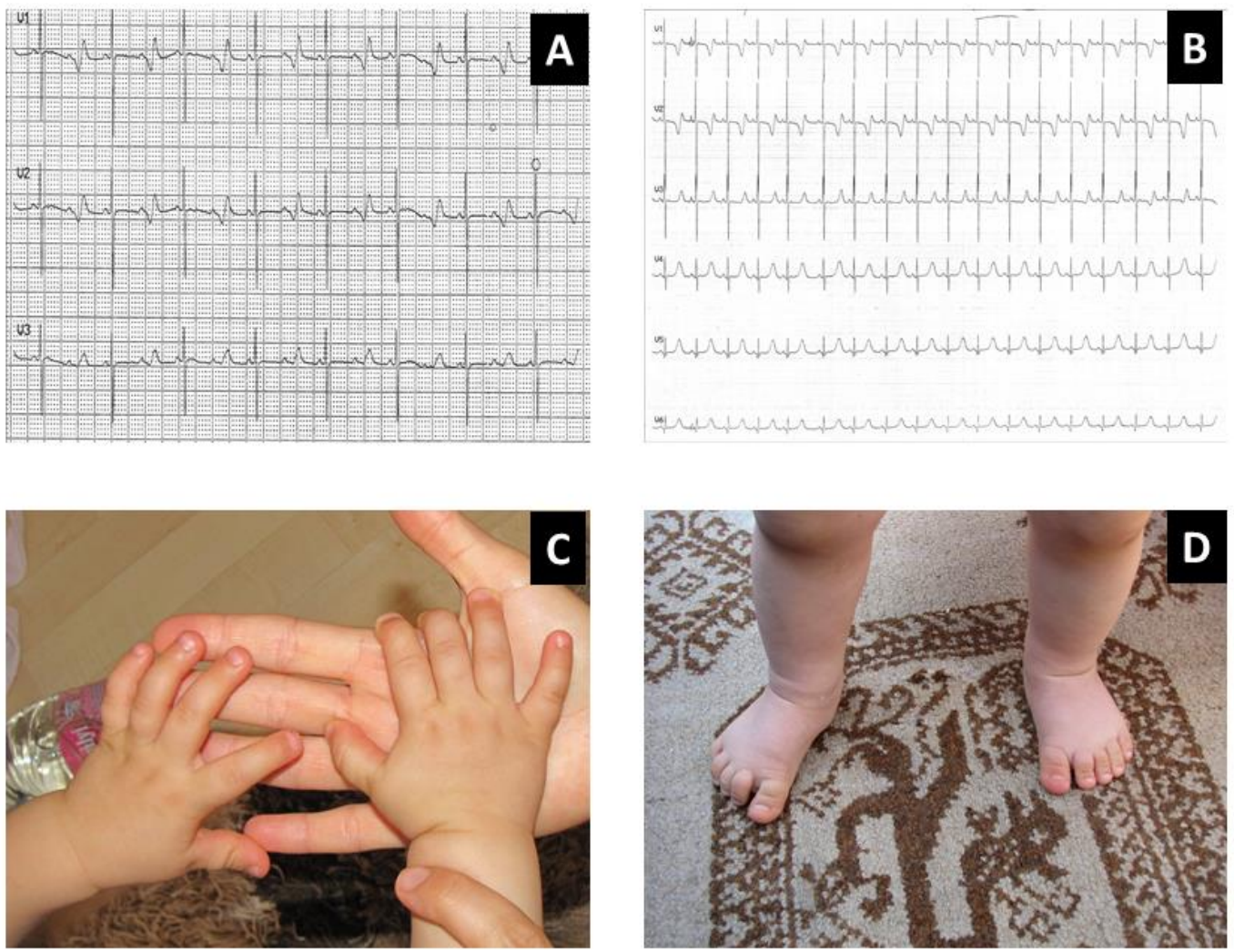

Figure 1. 12-lead ECG of the proband illustrating 2:1 AV block and marked QTc-interval prolongation of $600 \mathrm{~ms}$ at a heart rate of $72 \mathrm{bpm}$ (Panel A). On medical therapy (propranolol and mexiletine) 2:1 AV conduction resolved, and there is a consistent 1:1 AV conduction with QTc prolongation of $516 \mathrm{~ms}$ with T-wave alternans at a heart rate of $123 \mathrm{bpm}$ (Panel B). Paper speed $25 \mathrm{~mm} / \mathrm{s}$, calibration $10 \mathrm{~mm} / \mathrm{mV}$. Panel C and D: Photograph of the proband's hands and feet, at age 12 months, demonstrating no syndactyly of the fingers or toes. 


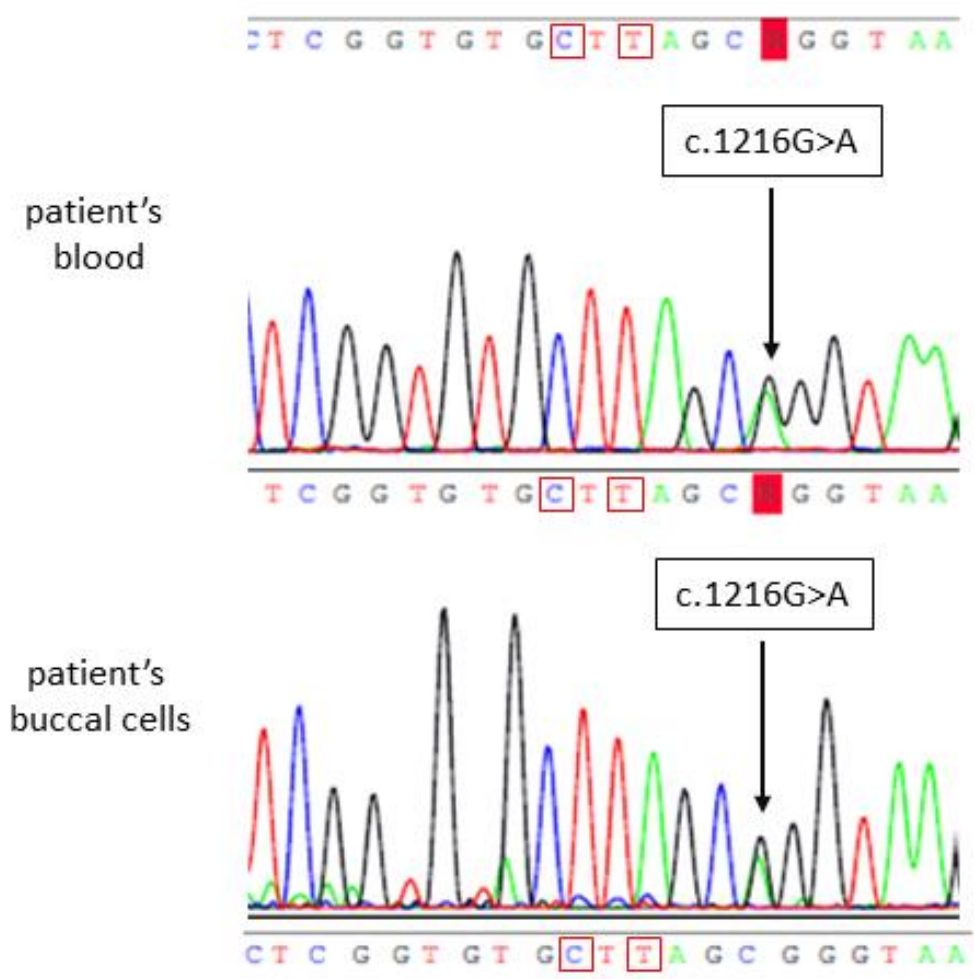

father's

blood

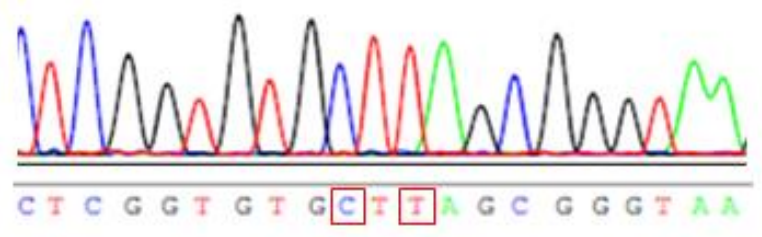

mother's

blood

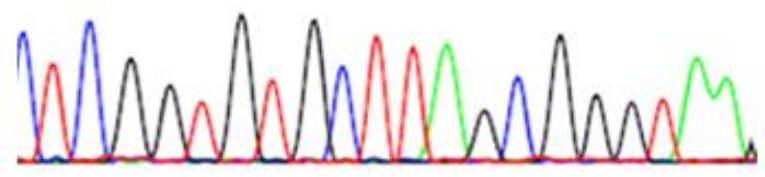

Figure 2. Sequence analysis of exon $8 \mathrm{~A}$ of the $C A C N A 1 C$ gene illustrating the c.1216G $>\mathrm{A}$ mutation. The mutation changes the GGA triplet at codon 406, encoding for glycine, to AGA, encoding for arginine (p.Gly406Arg). Sequencing result is shown from DNA isolated from 
blood (patient, father, mother) and from buccal cells (patient). Testing of parents suggested that the mutation is 'de novo'. Nucleotides framed in red are unique for exon $8 \mathrm{~A}$ when compared to homologous exon 8 . 
Table 1. Clinical and genetic characteristics of Timothy syndrome patients with proven genetic diagnosis reported in the literature.

\begin{tabular}{|c|c|c|c|c|c|c|c|}
\hline Report & $\begin{array}{l}\text { reported } \\
\text { pts. }(n)\end{array}$ & $\begin{array}{l}\text { TS } \\
\text { type }\end{array}$ & $\begin{array}{c}\text { affected } \\
C A C N A 1 C \\
\text { exon }\end{array}$ & $\begin{array}{l}\text { CACNAIC } \\
\text { mutation }\end{array}$ & $\begin{array}{l}\text { QT interval and } \\
\text { arrhythmia }\end{array}$ & $\begin{array}{l}\text { additional cardiac } \\
\text { phenotype }\end{array}$ & main additional symptoms \\
\hline $\begin{array}{l}\text { Splawski et al, } \\
2004^{2}\end{array}$ & 13 & TS1 & $8 \mathrm{~A}$ & Gly406Arg & $\begin{array}{l}\text { QT prolongation } \\
(100 \%), \mathrm{VT}(71 \%), \\
\text { bradycardia, } \mathrm{AV} \\
\text { block }(94 \%)\end{array}$ & $\begin{array}{l}\text { PDA }(59 \%), \text { PFO } \\
(29 \%), \text { VSD }(18 \%), \\
\text { cardiomegaly } \\
(35 \%)\end{array}$ & $\begin{array}{c}\text { autism/autism spectrum } \\
\text { disorder }(60-80 \%), \text { bald at } \\
\text { birth }(100 \%), \text { small teeth } \\
(100 \%) \text {, recurrent infections } \\
(43 \%), \text { facial dysmorphia } \\
(53 \%)\end{array}$ \\
\hline $\begin{array}{l}\text { Lo-A-Njoe et } \\
\quad \text { al, } 2005^{9}\end{array}$ & 2 & TS1 & $8 \mathrm{~A}$ & Gly406Arg & $\begin{array}{l}\text { QT prolongation, } \\
\text { bradycardia, AV } \\
\text { block, VT }\end{array}$ & HCM, PDA, HF & fetal hydrops \\
\hline $\begin{array}{l}\text { Krause et al, } \\
2011^{8}\end{array}$ & 1 & TS1 & $8 \mathrm{~A}$ & Gly406Arg & $\begin{array}{l}\text { QT prolongation, } \\
\text { bradycardia, AV } \\
\text { block, VT }\end{array}$ & HCM, VSD, PDA & lower set ears and bald head \\
\hline $\begin{array}{l}\text { Etheridge et al, } \\
\qquad 2011^{7}\end{array}$ & 2 & TS1 & $8 \mathrm{~A}$ & Gly406Arg & $\begin{array}{l}\text { QT prolongation, } \\
\text { bradycardia, AV } \\
\text { block, VT }\end{array}$ & VSD & $\begin{array}{l}\text { widely spaced eyes, broad } \\
\text { forehead, wide nasal bridge, } \\
\text { broad nasal tip }\end{array}$ \\
\hline $\begin{array}{l}\text { Dufendach et } \\
\text { al, } 2013^{5}\end{array}$ & 1 & TS1 & $8 \mathrm{~A}$ & Gly406Arg & $\begin{array}{l}\text { QT prolongation, } \\
\text { bradycardia, AV } \\
\text { block }\end{array}$ & none & \\
\hline An et al, $2013^{3}$ & 1 & TS1 & $8 \mathrm{~A}(9)^{*}$ & Gly406Arg & $\begin{array}{l}\text { QT prolongation, } \\
\text { bradycardia, AV } \\
\text { block, CA }\end{array}$ & none & $\begin{array}{l}\text { round face, small upper jaw } \\
\text { and teeth, nearly bald head }\end{array}$ \\
\hline $\begin{array}{l}\text { Corona-Rivera } \\
\text { et al, } 2015^{4}\end{array}$ & 1 & TS1 & $8 \mathrm{~A}$ & Gly406Arg & $\begin{array}{l}\text { QT prolongation, AV } \\
\text { block }\end{array}$ & PDA, PFO & fetal hydrops \\
\hline $\begin{array}{l}\text { Ergül et al, } \\
2015^{6}\end{array}$ & 1 & TS1 & $8 \mathrm{~A}$ & Gly406Arg & $\begin{array}{l}\text { QT prolongation, } \\
\text { bradycardia, AV } \\
\text { block, CA }\end{array}$ & PDA, PFO & $\begin{array}{l}\text { neuro-motor development } \\
\text { retardation, facial dysmorphia }\end{array}$ \\
\hline $\begin{array}{l}\text { Splawski et al, } \\
2005^{14}\end{array}$ & 1 & $\mathrm{TS} 2$ & 8 & Gly406Arg & $\begin{array}{l}\text { QT prolongation, } \\
\text { bradycardia, AV } \\
\text { block, VT, CA }\end{array}$ & $\begin{array}{l}\text { HCM, biventricular } \\
\text { dysfunction }\end{array}$ & $\begin{array}{c}\text { mental retardation, nemaline } \\
\text { myopathy, facial dysmorphia, } \\
\text { seizures }\end{array}$ \\
\hline $\begin{array}{l}\text { Splawski et al, } \\
2005^{14}\end{array}$ & 1 & TS2 & 8 & Gly402Ser & $\begin{array}{l}\text { QT prolongation, VT, } \\
\text { CA }\end{array}$ & $\mathrm{HCM}$ & $\begin{array}{c}\text { facial dysmorphia, recurrent } \\
\text { infections }\end{array}$ \\
\hline $\begin{array}{l}\text { Fröhler et al, } \\
2014^{11}\end{array}$ & 2 & TS2 & 8 & Gly402Ser & $\begin{array}{l}\text { QT prolongation, VT, } \\
\text { CA }\end{array}$ & none & no \\
\hline
\end{tabular}




\begin{tabular}{|c|c|c|c|c|c|c|c|}
\hline $\begin{array}{l}\text { Hiippala et al, } \\
2014^{12}\end{array}$ & 1 & TS2 & 8 & Gly402Ser & $\begin{array}{l}\text { QT prolongation } \\
\text { (mild), CA }\end{array}$ & none & no \\
\hline $\begin{array}{l}\text { Diep et al, } \\
2015^{10}\end{array}$ & 1 & $\mathrm{TS} 2$ & 8 & Gly406Arg & $\begin{array}{l}\text { QT prolongation, AV } \\
\text { block, VT }\end{array}$ & PDA, PFO & $\begin{array}{l}\text { hypotension, metabolic } \\
\text { acidosis, recurrent apnea, } \\
\text { seizure-like activity, poor } \\
\text { growth, facial dismorphia }\end{array}$ \\
\hline $\begin{array}{l}\text { Philipp et al, } \\
2016^{13}\end{array}$ & 1 & TS2 & 8 & Gly406Arg & $\begin{array}{l}\text { QT prolongation, AV } \\
\text { block, VT, CA }\end{array}$ & $\begin{array}{l}\text { PDA, biventricular } \\
\text { systolic dysfunction }\end{array}$ & $\begin{array}{c}\text { intermittent hypoglycemia, } \\
\text { hypocalcemia }\end{array}$ \\
\hline $\begin{array}{l}\text { Gillis et al, } \\
2012^{17}\end{array}$ & 1 & $\mathrm{TS}$ & 38 & Ala1473Gly & $\begin{array}{l}\text { QT prolongation, AV } \\
\text { block, VT }\end{array}$ & PDA, PFO & $\begin{array}{c}\text { facial dysmorphism, } \\
\text { contractures, episodes of } \\
\text { hypoglycemia, hypocalcemia, } \\
\text { seizures, cortical blindness, } \\
\text { developmental delay } \\
\text { seizures, cerebral and }\end{array}$ \\
\hline $\begin{array}{l}\text { Boczek et al, } \\
2015^{16}\end{array}$ & 1 & $\mathrm{TS}$ & 27 & Ile1166Thr & $\begin{array}{l}\text { QT prolongation, AV } \\
\text { block }\end{array}$ & $\begin{array}{l}\text { PDA, biventricular } \\
\text { dysfunction }\end{array}$ & $\begin{array}{l}\text { cerebellar atrophy, facial dys- } \\
\text { morphism, clinodactyly, } \\
\text { respiratory failure }\end{array}$ \\
\hline $\begin{array}{l}\text { Wemhöner et } \\
\text { al, } 2015^{18}\end{array}$ & 1 & $\mathrm{TS}$ & 27 & Ile1166Thr & QT prolongation, CA & PDA, HCM & developmental delay \\
\hline
\end{tabular}

TS: Timothy syndrome; PDA: patent ductus arteriosus; PFO: patent foramen ovale; VSD: ventricular septal defect; HCM: hypertrophic cardiomyopathy; VT: ventricular tachycardia; AV: atrio-ventricular; CA: cardiac arrest

*reported as exon 9, but based on direct sequence comparison it corresponds to exon $8 \mathrm{~A}$ 